\title{
Biotechnology in the restoration of extinct animal species. An analysis of genomic and mitochondrial DNA of aurochs
}

\author{
Daniel Lipiński ${ }^{1,2}$, HanNa PrZystalowska ${ }^{1}$, Marlena SZalata ${ }^{1,2}$, JoANNa Zeyland ${ }^{1}$, \\ Karolina Wielgus ${ }^{3}$, Hieronim FrącKowiaK ${ }^{1}$, AleXANDER M. DZIEDUSZYCKI ${ }^{4}$, \\ MIROSŁAW S. RYBA ${ }^{4}$, RYSZARD SŁOMSKI ${ }^{1,2 *}$ \\ ${ }^{1}$ Poznań University of Life Sciences, Poznań, Poland \\ ${ }^{2}$ Institute of Human Genetics, Polish Academy of Sciences, Poznań, Poland \\ ${ }^{3}$ Institute of Natural Fibres and Medicinal Plants, Poznań, Poland \\ ${ }^{4}$ Polish Foundation for Restoration of the Aurochs, Warszawa, Poland \\ * Corresponding author: slomski@up.poznan.pl
}

The aurochs is a species similar to the African Buffalo, Water Buffalo, Muskox, Yak, Wisent or Bison. According to J. Rostafiński "aurochs was similar to an ox from the Podolia region and the Hungarian Ox and also to Andalusian Bulls" (Ossendowski, 1936). The description of the species may be deduced from several sources. The oldest sources are the pictures, reliefs and cave paintings dating back to about 17,000 (and more) years ago. The other sources are: Sumerian, Egyptian, Greek, or Roman descriptions originating during the time of the conquests of Gaul and Germania, Germanic sagas and songs (written in the runic alphabet), and more modern reports, mainly German and Swiss, which describe aurochs in the Baltic territory including Poland, as well as in Moldova. The most reliable are Polish descriptions, especially those from the $15-17^{\text {th }}$ centuries. The most limited, although also the most objective source, are the remains of those animals found in Europe, Africa and Asia. Although the found remains allow us to precisely establish certain features of the aurochs, nothing may be concluded about its external appearance and the features are dependent on the precision of dating.

Descriptions of aurochs are a rarity. Julius Caesar (100-44 B.C.) in About the Gallic War (Commentarii rerum gestarum belli Gallici or in another way De bello Gallico) wrote about the aurochs: “...these animals which are called uri. It is somewhat below the size of an elephant and has its appearance, colour and shape as a bull. Their strength and speed are remarkable; they spare neither a man nor a wild animal that is noticed by them. Germanic people catch them with huge pains into exca- vations and kill them. Young men toughen by the exercises and they practice themselves this type of hunting, and those who slaughter the largest number of them, showing in public their horns as proof, get the biggest prize. But even a very young animal cannot become docile and neither tame with a human. The size, shape and appearance of their horns considerably differ from the horns of our ox. These ones are searched for with anxiety and their ends are framed and used as cups during the most lavish parties" (Caesar, 58 B.C.).

Conrad Gessner (1551) in his work concerning quadrupeds, birds, fishes, snakes and scorpions known at his time, also published letters of Anton Schneeberger and Johann Bonar describing aurochs as: "a very agile animal, however not long-lived; they say that only a few of them lived longer than 15 years", "They gather in September, very excited, and often they wage battles with each other in which sometimes both sides fall down dead" (Lasota-Moskalewska, 2005). The letters suggest that calves born in autumn were weak and often did not survive severe winter. Before delivery, cows were going deep into backwoods where they stayed with their calves for about twenty days and then let them free in a pasture and looked after them with care.

The remains of aurochs that could be seen in many Polish museums were not considered very attractive as they were thought to be too "new". Therefore, they would fill up storerooms, or were handed over to schools. As a consequence, at present it is hard to put together a full skeleton of the aurochs (Fig. 1). 


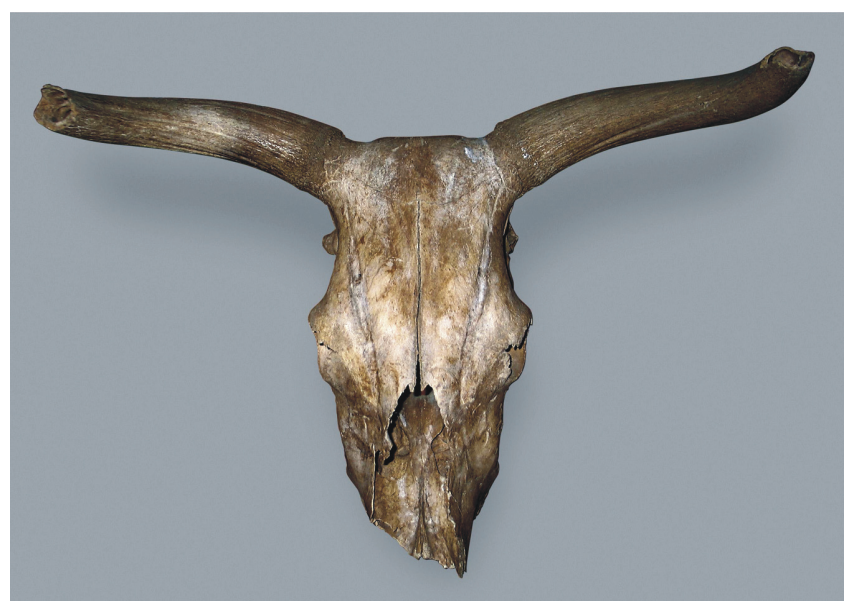

Fig. 1. Examples of an aurochs' skeleton found on the Polish territory. An excellently preserved skull from the collection of the Museum of Natural Environment and Hunting in Uzarzewo near Poznań. Remains of an aurochs are often found on the territory of Poland

It is commonly believed that the aurochs was an enormous animal with the height at the withers about 180-190 cm (bulls) and 160-175 cm (cows). As can be seen from many descriptions, sexual dimorphism was clear. The colour of the bulls ranged from very dark auburn to black and they had a lighter stripe along their back, while the cows had their colour from red to auburn. The horns of the bulls were longer, curved towards the front in the shape of lyre, directed upwards and converged together, by the ends, to the middle. Their horns reached over one meter in length (longest found was $1.5 \mathrm{~m}$ long).

There are many villages, towns and places in Poland whose names are connected with aurochs. The name of the Turek County in Poland raised certain controversies (in Polish the word "Tur" means "aurochs", while the word "Turek" may mean both "a small aurochs" or "a Turkish person”). Leon Lubomir Kruszyński, in the introduction to his work entitled "The Monograph of Turek Town" published in 1892, wrote that the name of the settlement of Turek came from the word "tur" (aurochs) otherwise "żubr" (a wisent) (Kruszyński, 1892).

The history of aurochs is estimated at about 2-1.5 million years. It is quite commonly believed that the animals derived originally from the territory of the Indian subcontinent from where they would have dispersed to Asia Minor and subsequently further deep into Asia and Europe. It is estimated that they reached Eu- rope about 250,000 years ago. It is also assumed that almost all European and African domestic cattle as well as the cattle of continental Asia derive from the aurochs. It is likely that their descendants could also be Zebu, Gaur and the half-mythical Kouprey cattle. Some morphological features of various breeds of the domestic cattle resemble respective features of the aurochs. These are, in particular, the primitive breeds, such as the Hungarian and Podolian Steppe Cattle, the Scottish ones, or the breeds of the Spanish Cattle used for fights.

History of the research into the aurochs dates back to the turn of the $18^{\text {th }}$ and $19^{\text {th }}$ centuries. In 1827 , Bojanus described an aurochs' skeleton and came to a conclusion that the animal was a separate species. He gave it a systematic name of the Carl Linnaeus' classification - Bos primigenius (Bojanus, 1827). In 1878, based on the analysis of previous calculations, Wrześniowski showed that the aurochs lived in Europe in the Holocene epoch together with the wisent (Wrześniowski, 1878). In 1927 , on the basis of the collected bone material, von Leithner announced that the aurochs was the only wild ancestor of the temporary domestic cattle and that there was a significant difference between an aurochs bull and an aurochs cow (von Leithner, 1927). Since then many researchers and hobbyists-enthusiasts have traced clues of the aurochs all over Europe and even beyond its borders. Polish researchers seem to be exceptionally privileged to live in an area where much important material lies 'at hand' which, often is not appreciated by Polish paleozoologists.

On the basis of available written sources as well as detailed research into the aurochs population and its living environment, it cannot be claimed with any certainty that the aurochs were killed off by humans. It seems that the process was much more complicated and lasted for a long time. Leon Mejnartowicz offered an interesting and practical view for the process, blaming the invaders from Asia (during the migration period towards the end of antiquity) for the significant decrease in the number of this species (1998). The research revealing that the average concentration of aurochs could amount to about 5 individuals on 100 ha of a forest speaks for the fact that such a low level of concentration could have weakened the genetic resources of the species. On the other hand, it is known that in the central and northern parts of the continent, the animal disappeared the ear- 
liest in isolated areas - on the British and Scandinavian Islands, even though there were favourable living conditions for them and people did not contribute to their extinction. Their disappearance was rather a result of the frequent replacements of the genetic material from the very extensive resources of genes that was needed to keep a healthy population. Consequently, the decrease in the population of aurochs in this way, along with the simultaneous, steady shrinkage of its natural living space and growing unequal competition with the domestic cattle, was in real danger.

For the longest time the aurochs survived in Poland. The decadent period of the aurochs falls during the Middle Ages. In the $13^{\text {th }}$ century, the aurochs inhabited the Masovia region in Poland, the Prussia-occupied land in Lithuania, Moldova and Transylvania. Traces of this animal originating in the $14^{\text {th }}$ century have been reported in Lithuania but soon after it disappeared, and the last herd remained in Masovia in the Jaktorów Primeval Forest in Poland. Even though King Sigismund I the Old took the last aurochs herd under special protection, providing it with year-long inspection and care with feeding, in 1627, the animal disappeared altogether from the history of the Earth near Jaktorów, where the last cow died, outliving the last bull by 7 years (Łukaszewicz, 1952). The last Polish king who hunted this animal was Władysław II Jagiełło, but those were rather occasional hunts, if not limited to only one occasion.

In 1523, King Sigismund II Augustus signed a document proclaiming the protection of wisent, aurochs, beaver, falcon and swan. In 1578, King Stephen Báthory issued a decree prohibiting the use of trawls, boat-hooks and fishnets with too small holes. Furthermore, fishing during spawning-season was not allowed. Although King Sigismund III Vasa reinforced the protective statute of the aurochs in the Jaktorów Primeval Forest, the last aurochs nevertheless died during his reign. During that period, Poland belonged to the countries which attached huge importance to the protection of the natural environment and preservation of biodiversity.

It is generally assumed that all contemporary breeds of domestic cattle come from one of the three subspecies of the aurochs. It is also possible that most of the breeds have derived from $B$. primigenius. Such assumptions are based on the morphological similarity of the animals drawn from the old drawings and much older paintings, and on the anatomical similarities between the aurochs and cow skeletons. However, the fossil material is still poor. There are no more arguments that would speak for such a hypothesis, than there are questions and doubts. Though the most important arguments are the preliminary genetic comparisons conducted in the 1990s (Bailey et al., 1996).

There are many other arguments against the thesis about the origins of domestic cattle from the aurochs. Among them a relevant one is the historical evidence proving that taming the aurochs was never a possibility, not even its calves that were kept together with domestic cattle (Caesar, 58 B.C.; Lasota-Moskalewska, 2005). Another description says that domestic cows fertilized by aurochs bulls either miscarried early or gave birth to a dead offspring (Gessner, 1551). These facts may suggest that the relationship between domestic cattle and aurochs was further than the one of horse and donkey.

In principle, we can imagine two ways of restoring the aurochs. The first one would be through a genetic modification, in the result of which the bovine genome would be used as a "basis" to introduce aurochs' genes obtained earlier from fossil material. This method could be called "the aurochsation" of cattle. While the second one, which is comparably more arduous, would consist of restoring and duplicating the complete aurochs genome, and cloning it afterwards, using a cow of the contemporary species Bovidae. Neither of these two methods is an attempt to create a species in the meaning of ex nihilo.

The first research concerning the aDNA from animal tissue was conducted by Higuchi in 1984 and the research concerning a human tissue was done by Pääbo in 1985 on the aDNA of Egyptian mummies. In the pioneering research, reaching a success was dependent on gaining relatively large quantities of good quality DNA. The introduction to laboratories of the polymerase chain reaction (PCR) (which enabled to amplify DNA in vitro) popularized the aDNA research and also enabled the utilization of genetic material, partially damaged as a result of the working of environmental factors.

Molecular research with the aurochs is still relatively infrequent, although the first encouraging results have already been published. An interesting example is the research into the Plains Zebra (Equus quagga quagga). The last animals of this kind died in the Amsterdam ZOO in 1883, in the wild however, the last ones had been hunted down in Southern Africa about 1878. A Plains Zebra 
was the first extinct species of animals for which DNA research was embarked on. From the museum pieces of a dried muscle of a Plains Zebra being preserved for more than 150 years, a DNA sample was obtained in a quantity not exceeding $1 \%$ of the amount usually occurring in a muscle. There appeared a possibility of researching DNA included within the cell nucleus and mitochondria. Two fragments of the mitochondrial DNA (mtDNA) have been sequenced. Analysis of a 229 base pairs long fragment revealed 12 single nucleotide mutations in comparison with the homologous sequence from a zebra, which points to a common ancestor living 3-4 million years ago (Higuchi et al., 1984).

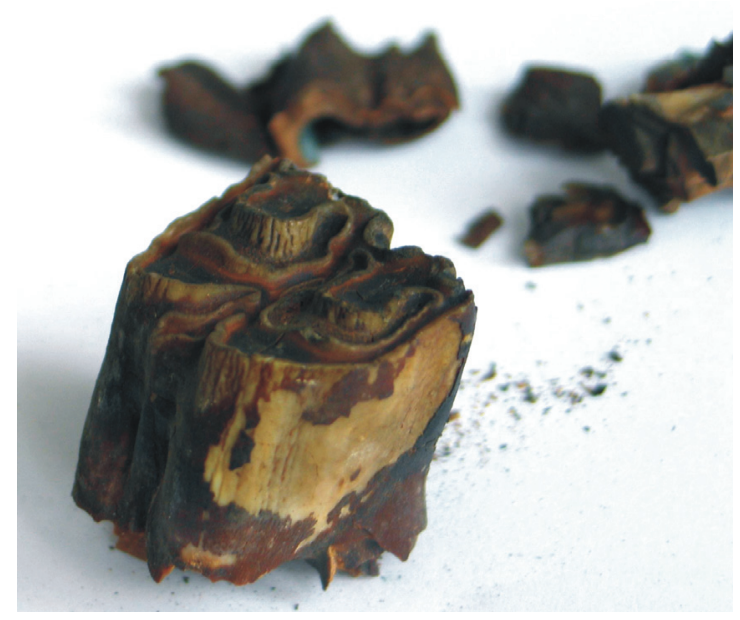

Fig. 2. Fragments of an aurochs' teeth from the collection of the Institute of Agricultural and Forest Environment of the Polish Academy of Sciences in Poznan - starting material for DNA isolation

Aurochs research can be conducted on the basis of the preserved bones and teeth accessible in a museum, or from private or recently found collections. The remains are usually found in the early medieval material, or are gained during digging peat or regulating rivers. First analyzed are all fragments of cornual processes (beginnings of horns) as well as the teeth of aurochs (Fig. 2). For comparative research blood samples were collected from the Banteng, Yak, Wild Water Buffalo, Ankole-watusi and Steppe Cattle as well as from various breeds of domestic cattle. The material delivered to a laboratory was taken from the inside of the bones or teeth, in order to limit possibilities of contamination by the contemporary DNA or impurities by conservants which often contain bone glue. The surface of the bone was additionally purified using fine sandpaper.

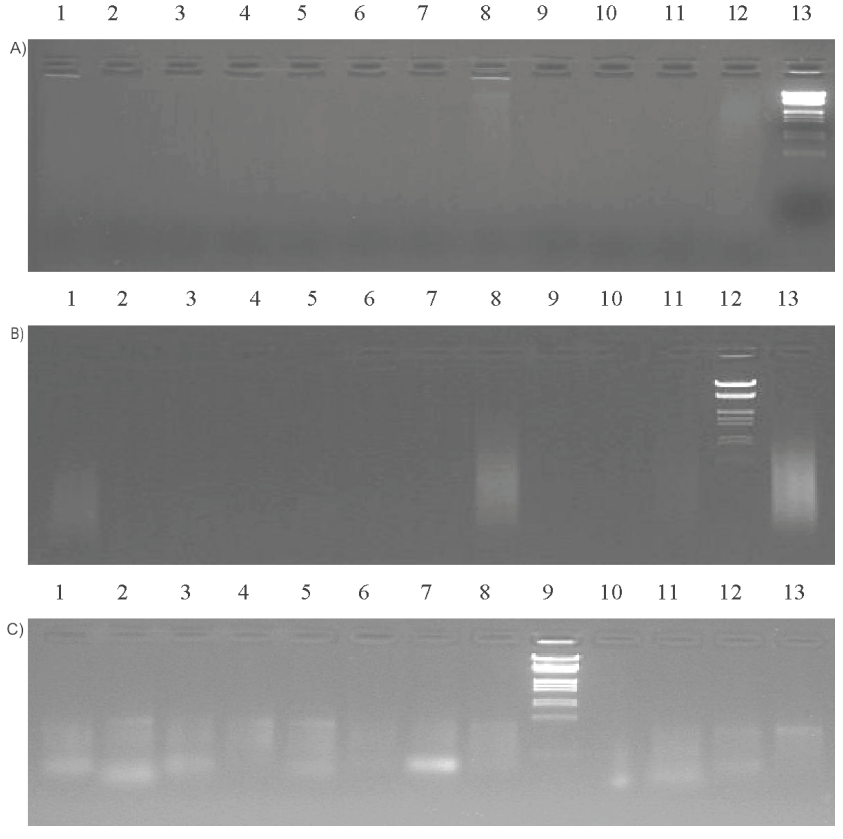

Fig. 3. (A) Isolation of genetic material - aurochs aDNA isolated from bone remains. DNA samples were separated in a $1 \%$ agarose gel. Lanes 1-12, aurochs aDNA from different isolates, lane 13 , size marker ( $\lambda \mathrm{DNA} /$ Hind III $+E c o \mathrm{RI})$. In lanes 1,8 and 12 the aurochs DNA preparations are visible as smears. However, high molecular weight DNA fully suitable for further molecular research is also present; (B) Application of whole genome amplification (WGA) strategy in the analysis of aurochs DNA. In lanes 1-11 and 13 the products of WGA reactions; lane 12 , size marker ( $\lambda \mathrm{DNA} /$ Hind $\mathrm{III}+E c o \mathrm{RI})$. In lanes $1,8,11$ and 13, the product of WGA amplification of aurochs genomic DNA is clearly visible. DNA fragments obtained from aurochs showed the same quality as fragments; (C) Amplification products of mitochondrial DNA fragments. $500 \mathrm{bp}$ long fragments obtained for sample 1 were used for cloning. Lane 9, size marker( $\lambda$ DNA/Hind III $+E c o$ RI $)$

Environmental conditions in which the bones were preserved for many years are responsible for the fact that only a small part of genetic material i.e. cellular DNA, can be isolated and its quality is much lower than that of the contemporary DNA. Very often the quantities of the aDNA are so small that they cannot be precisely estimated. In Figure 3A, preparations of the contemporary DNA of cattle and the aDNA isolated from the aurochs are presented. The ancient DNA of aurochs presents a totally different picture when compared with contemporary DNA. In place of a DNA band, a smear can be observed which is formed by DNA fragments of different sizes. Occurrence of the DNA smear suggests that large DNA fragments still have survived and can be analysed using molecular biology methods. 
After obtaining the aurochs' aDNA, another important stage of work is to determine its quantity. The concentration of DNA was determined by measurement of UV light absorption. In the case of aDNA from fossil material, level of DNA degradation should be taken into account. This phenomenon was visible for the spectra made for the aurochs' DNA, where the typical shape of the spectrum was retained, although strongly flattened.

In the next stage, the isolated DNA was subjected to the procedure of the whole genome amplification (WGA) in order to increase the quantity of DNA for further work and for the preparation of the DNA for cloning in E. coli. The WGA method enabled representative amplification of the whole genome, protecting the starting sample of DNA for further analyses of particular genes. Usually amplification of 1 nanogram of genomic DNA resulted in several micrograms of DNA for further analyzes (Fig. 3B and 3C).

The products of the WGA reaction were inserted into plasmid $p G E M$-T Easy (3018 bp) and were used for transformation of $E$. coli. Bacterial colonies were grown over night at a temperature of $37^{\circ} \mathrm{C}$ in an incubator with the shaking-out function, in the presence of ampicillin $(100 \mu \mathrm{g} / \mathrm{ml})$. Figure 4 shows plasmid preparations with aurochs DNA marked by red arrows, while the white arrow indicates a plasmids in which the fragment of the aurochs' DNA was not inserted. Finally, the fragments of the aurochs' DNA, built into the plasmid pGEM-T Easy, have been subjected to sequencing.

The DNA sequencing of aurochs genomic DNA is pending and first comparative analyses are expected soon. At present, we have included, in our research, mtDNA gained from a Yak, Steppe Cattle, Ankole-Watusi Cattle and Wild Water Buffalo. The ancient DNA is most often degraded and that is why the mtDNA occurring in a cell in many copies can be easily gained for further research than the nuclear DNA which occurs only in two copies in cells of diploid organisms. In one cell there occur several hundred of mitochondria and in each of them there are 2-10 copies of the mitochondrial DNA. A mitochondrial genome has many features, which can be useful during molecular analyses. First of all, its size is relatively small, i.e. $16,569 \mathrm{bp}$. One of the earliest achievements of the authors is the characterization of mitochondrial DNA (mtDNA) from the tooth of a man living 3000 years ago found in the collection of the Museum of Warmia and Masuria in Olsztyn, Poland (Wielgus et al., 2008).

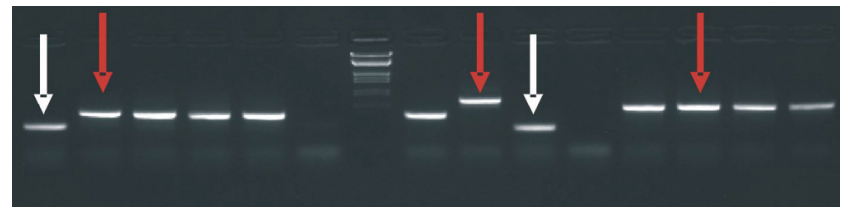

Fig. 4. Cloned fragments of aurochs DNA after electrophoretic separation in a $1.5 \%$ agarose gel. The red arrows indicate the cloning products whose size suggests the presence of the aurochs mtDNA insert. For comparison, the white arrows indicate the products whose size excludes the presence of the aurochs mtDNA. Plasmids with inserts were subjected to DNA sequencing

On the basis of the reference sequence of the mtDNA of domestic cattle (GenBank AY526085), specific PCR primers were designed and subsequently used for the amplification of the following aurochs mitochondrial genes: $\mathrm{NADH}$ dehydrogenase subunit 6 (nd6), NADH dehydrogenase subunit 5 (nd5), NADH dehydrogenase subunit 1 (nd1) and cytochrome c oxidase subunit I $(\operatorname{cox} 1)$. The applied nested-PCR strategy enabled us to successfully acquire PCR products of the assumed size in two cases.

The PCR products were cloned into the plasmid vector $p G E M-T$ Easy. To make the cloning easier, the Taq polymerase connecting additional adenine on the 3 ' ends was used to obtain PCR products. Accordingly a cloning vector has complementary thymine on the 5 ' ends. In this way, the productivity of the ligation reaction, which is not a very efficient process, has been improved. Thereafter, to confirm the recombination by the colonial PCR method, the introduced DNA fragments were amplified with the help of the pGEMF and pGEMR primers specific to the regions flanking a multiple cloning site (MCS). After the preliminary selection of clones by the colonial PCR method, plasmid DNA selected from bacterial colonies was isolated and subjected to sequencing by the cyclic sequencing method with the application of the M13F and M13R primers.

Each clone was subjected to sequencing twice, and the obtained mtDNA sequences were analysed with the help of the ChromasPro software (http://www. technelysium.com.au/ChromasPro.html). Then, the obtained sequences were compared by employing the BLAST soft ware with the reference sequence of the aurochs $\mathrm{mtDNA}$ (GenBank GU985279) available in the GenBank sequence database. The comparative analysis showed differences between the compared fragments (Fig. 5 and 6 ). The acquired fragments were located within the cytochrome c oxidase subunit I - cox1 (5687-7231 bp) gene. 


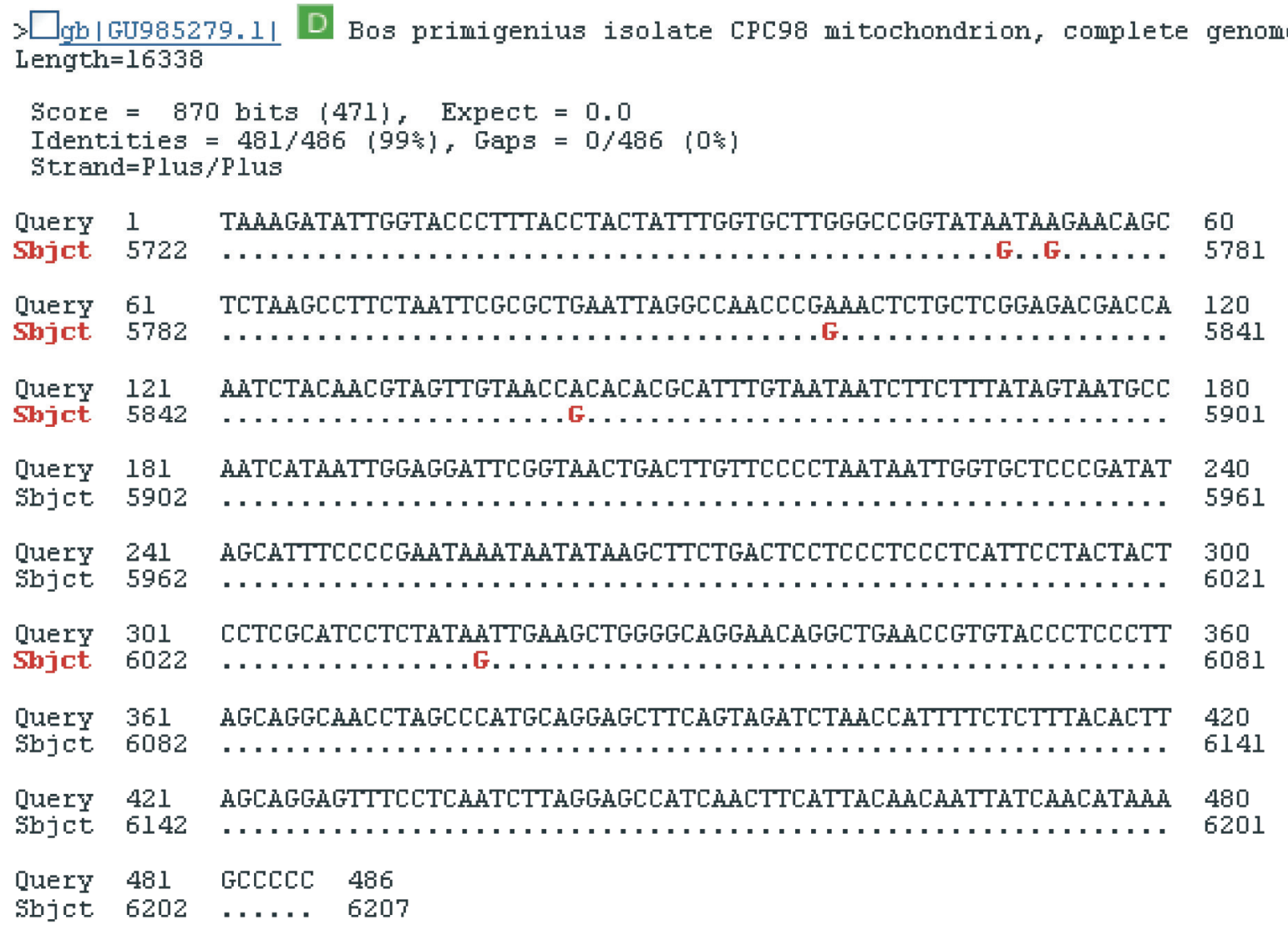

Fig. 5. The comparative analysis - made with the help of the BLAST software - of the cloned aurochs mtDNA sequence (the clone 171, query) and the reference sequence of the aurochs mtDNA (GU985279.1, sbjct) available in the GenBank sequence database showed very high identity - 99\%. In comparison with reference mtDNA 5 single nucleotide changes were observed

In November 2008, when geneticists published the near-complete DNA sequence of the woolly mammoth, there was much discussion whether researchers could bring it back to life (Miller et al., 2008). Creating a living creature from a genome sequence that exists only as DNA sequence is not possible right now. "But someone someday is sure to try it”, predicts Stephan Schuster, a molecular biologist at Pennsylvania State University, USA, involved in mammoth genome project. The genomes of several extinct species besides the mammoth are already being sequenced, but turning these into living creatures will not be easy "It is hard to say that something will never ever be possible" says Svante Pääbo of the Max Planck Institute for Evolutionary Anthropology in Leipzig, Germany, "but it would require technologies so far removed from what we currently have that I cannot imagine how it would be done" (Nichols 2009), assuming that technology will be developed, Henry Nichols has selected 10 extinct species that might one day be restored. The list opens Saber-toothed tiger (Smilodon fatalis), extinct 10,000 years ago, followed by Neanderthal man (Homo neanderthalensis), extinct 25,000 years ago; Short-faced bear (Arctodus simus), extinct 11,000 years ago; Tasmanian tiger (Thylacinus cynocephalus), extinct in 1936; Glyptodon (Doedicurus clavicaudatus), once living in the South America, extinct 11,000 years ago; Woolly rhinoceros (Coelodonta antiquitatis), extinct 10,000 years ago; Dodo (Raphus cucullatus), extinct in 1690; Giant ground sloth (Megatherium americanum), extinct 8,000 years ago; Moa (Dinornis robustus), extinct in 1500; Irish elk (Megaloceros giganteus), extinct 7,700 years ago; Giant beaver (Castoroides ohioensis), extinct 10,000 years ago and almost extinct Gorilla ( $G o$ rilla gorilla). The first species to be brought back from extinction will, most likely, be the one that is alive today. Conservationists are freezing tissue samples from some threatened species, so that clones could be created with the help of a closely related surrogate species if a suitable habitat becomes available. For gorillas, the surrogate would be the chimpanzee. 

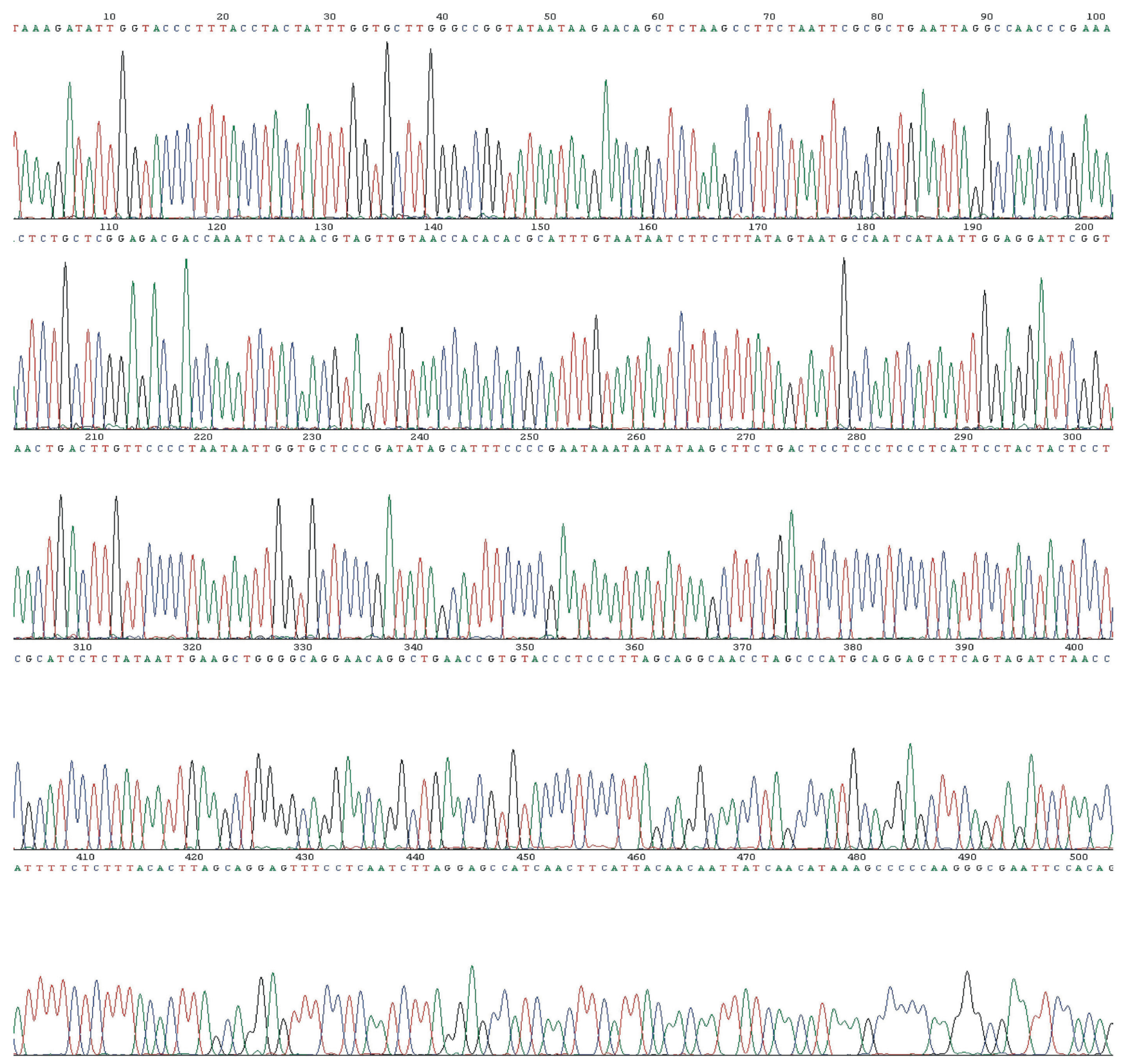

\section{TAAAGATATTGGTACCCTTTACCTACTATTTGGTGCTTGGGCCGGTATAATAAGAACAGCTCTAAGCCTTCTAATTCGCG CTGAATTAGGCCAACCCGAAACTCTGCTCGGAGACGACCAAATCTACAACGTAGTTGTAACCACACACGCATTTGTAATAA TCTTCTTTATAGTAATGCCAATCATAATTGGAGGATTCGGTAACTGACTTGTTCCCCTAATAATTGGTGCTCCCGATATAG CATTTCCCCGAATAAATAATATAAGCTTCTGACTCCTCCCTCCCTCATTCCTACTACTCCTCGCATCCTCTATAATTGAAG CTGGGGCAGGAACAGGCTGAACCGTGTACCCTCCCTTAGCAGGCAACCTAGCCCATGCAGGAGCTTCAGTAGATCTAACC ATTTTCTCTTTACACTTAGCAGGAGTTTCCTCAATCTTAGGAGCCATCAACTTCATTACAACAATTATCAACATAAAGCCC CCAAGGGCGAATTCCACAGT}

Fig. 6. The sequence of clone 171 encompassing mtDNA fragment (5722-6207 bp mtDNA). Changed nucleotides were yellow highlighted. In the top part the sequence is presented in a graphic form; below - the full sequence read

What we expect to learn from our research is whether it is right to talk today about the restoration of extinct species as it mainly arouses controversies at the moment?
No one can say that no more breakthroughs are possible in science or that successive discoveries are impossible. A general scheme for restoration of extinct species is presented in Figure 7. 
In vitro fertilization using frozen semen

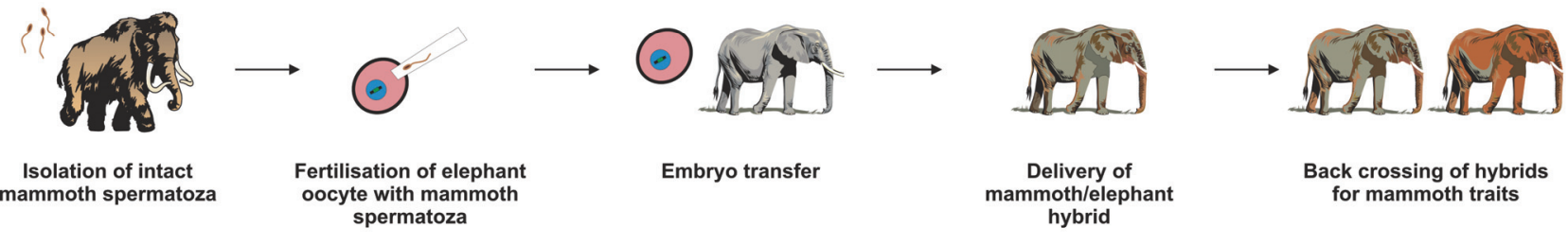

Cloning of frozen cell
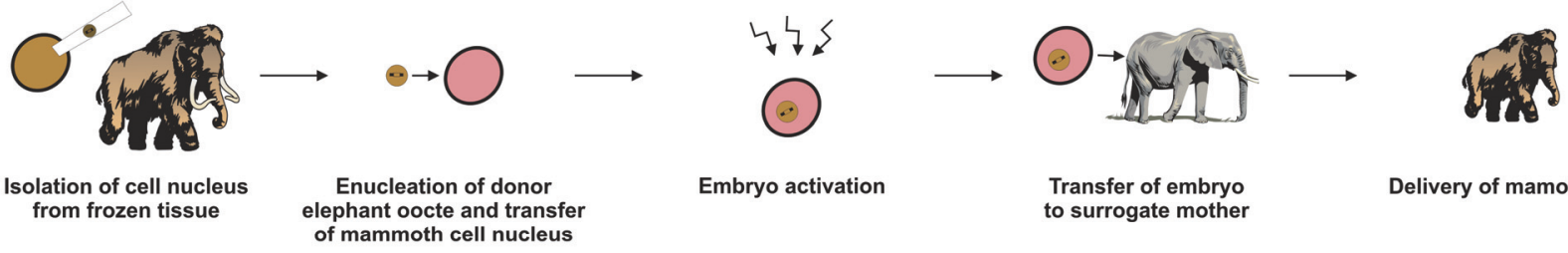

Transfer of embryo
to surrogate mother

Delivery of mamoth calf

Cloning based on DNA sequence

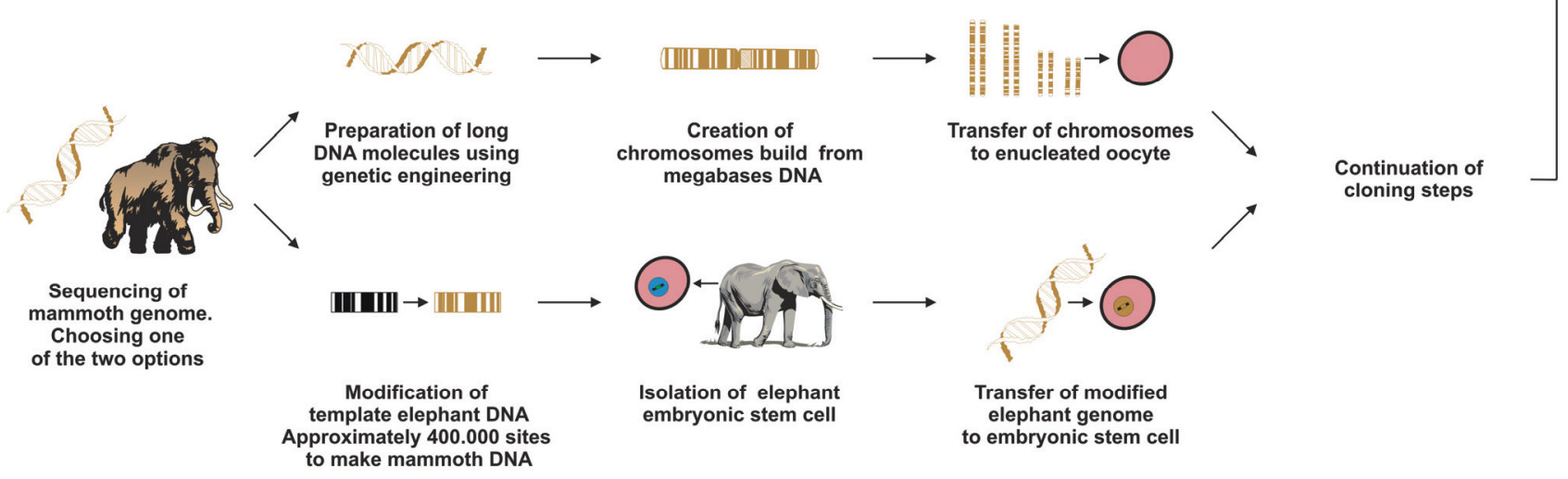

Fig. 7. Three scenarios of mammoth species restoration

One more important thing that emerged from the discussions carried out during the First International Conference on the Restoration of Endangered and Extinct Animals held in Jastrzębiec near Warsaw, Poland (7-19 May, 2010), is that the question about the feasibility of the restoration of species rejects extreme pessimism and accepts the view that what was impossible only a few years ago appears to be within reach today. More and more frequently, one hears researchers say: "Yes, a few years ago such statements seemed funny but today I see things differently."

The researches for the restoration of aurochs, initiated by the Polish Foundation for the Restoration of the Aurochs, within a short period of merely two years, have borne fruit already. One of the most important achievements has been the triggering off a wide discussion about aurochs, which means in fact that aurochs has already come back to life (Dzieduszycki et al., 2010; Słomski, 2010). Attention has been drawn towards the necessity of protecting the free-living animals and towards huge difficulties accompanying the exploration of extinct species.

\section{References}

Bailey J.F., Richards M.B., Macaulay V.A., Colson I.B., James I.T., Bradley D.G., Hedges R.E., Sykes B.C. (1996) Ancient DNA Suggests a Recent Expansion of European Cattle from a Diverse Wild Progenitor Species. Proc. R. Soc. Lond. B. 263: 1467-1473.

Bojanus L.H. (1827) Nova Acta Physico-Medica Academiae Caesareae Leopoldino-Carolinae Naturae Curiosorum, Bonn.

Dzieduszycki A.M., Słomski R., Ryba M.S. Will an Aurochs Come Back to Polish Forests? Poznań University of Life Sciences 2010: 1-135.

Gessner K. Historia animalium. 1551-1558, vol. I-IV. 
Higuchi R., Bowman B., Freiberger M., Ryder O.A., Wilson A.C. (1984) DNA sequences from the quagga, an extinct member of the horse family. Nature 312: 282-284.

Kruszyński L.L. (2007) Turek. Monography of Town. Monografja Miasta. Ed. Rybacki K., Łowicz 1892. Collection of Works. Bibliotheca Turcoviana 2007: 1-291.

Lasota-Moskalewska A. (2005) Zwierzęta udomowione $w$ dziejach ludzkości. WUW, Warszawa 2005: 55.

Łukaszewicz K. (1952) The ure-ox. Environment Protection. Ochrona Przyrody 20: 1-33.

Mejnartowicz L. (1998) Dlaczego zginął tur? Łowiec Polski 1: 18-20.

Miller W., Drautz D.I., Ratan A., Pusey B., Qi J., Lesk A.M., Tomsho L.P., Packard M.D., Zhao F., Sher A. et al. (2008) Sequencing the nuclear genome of the extinct woolly mammoth. Nature 456 (7220): 387-390.

Nicholls H. (2009) Ten extinct beasts that could walk the Earth again. New Scientist 2690: 24-28.

Ossendowski F.A. (1936) Polish Primeval Forests. Ed. Wegner R., Poznań 1936: 43-52.
Pääbo S. (1985) Molecular cloning of ancient Egyptian mummy DNA. Nature 314: 644-645.

Słomski R. (2010) Restoration of Endangered and Extinct Animals. Restoration of Endangered and Extinct Animals. Ed. Słomski R., Poznan University of Life Sciences Publisher 2010: 7-26.

von Leithner O. (1927) Der Ur. Berichte der Internationalen Gesellschaft zur Erhaltung des Wisents. T. II, Zeitschrift 1 und 2: 1-139.

Wielgus K., Lipiński D., Dzieduszycki A.M., Ryba M.S., Słomski R. (2008) Analysis of human mitochondrial DNA sequences from excavation material. Analysis of DNA. Theory and Practice. Ed. Słomski R., Poznań University of Life Sciences 2008: 398-408.

Wrześniowski A. (1878) Studien zur Geschichte des polnischen Tur. Zeitschr. Wissenschaft Zool. 30, Suppl. 45: 493-555. 